\title{
Detection of Caves by Gravimetry
}

\author{
By Raymundo J. Ghico ${ }^{1}$ )
}

With plates $18(1)-21(4)$

\section{Introduction}

A growing interest in locating caves - largely among non-speleologists - has developed within the last decade, arising from industrial or military needs, such as: (1) analyzing subsurface characteristics for building sites or highway projects in karst areas; (2) locating shallow caves under airport runways constructed on karst terrain covered by a thin residual soil; and (3) finding strategic shelters of tactical significance.

As a result, geologists and geophysicists have been experimenting with the possibility of applying standard geophysical methods toward void detection at shallow depths. Pioneering work along this line was accomplished by the U.S. Geological Survey Military Geology teams during World War II on Okinawan airfields. Nicol (1951) reported that the residual soil cover of these runways frequently indicated subsidence due to the collapse of the rooves of caves in an underlying coralline-limestone formation (partially detected by seismic methods).

In spite of the wide application of geophysics to exploration, not much has been published regarding subsurface interpretation of ground conditions within the upper 50 feet of the earth's surface. Recently, however, Romberg (1962) and Colley (1962) did report some encouraging data using the gravity technique for void detection.

This led to the present field study into the practical means of how this complex method can be simplified, and to a use-and-limitations appraisal of gravimetric techniques for speleologic research.

\section{Principles and Corrections}

The fundamentals of gravimetry are based on the fact that natural or artificial voids within the earth's surface - which are filled with air (negligible density) or water (density about $1 \mathrm{gm} / \mathrm{cm}^{3}$ ) - have a remarkable density contrast with the surrounding rocks (density 2.0 to

\footnotetext{
1) 4609 Keswick Road, Baltimore 10, Maryland, U.S.A.
} 
$2.7 \mathrm{gm} / \mathrm{cm}^{3}$ ), giving rise, therefore, to gravity-minimum values. The vertical attraction of these masses is governed by Newton's law of gravitation and is indirectly measured in milligals ${ }^{2}$ ) with gravimeters (Figure 1). These instruments have frequently been used in locating masses of contrasting density within the earth's crust such as salt plugs and subsurface unconformities (Billings, 1952); in another case, chromite deposits (Hammer, Nettleton, and Hastings, 1945), and still another, flat sulfide orebodies (Goetz, 1957).

The techniques and theoretical treatment of gravimetry are fully detailed in geophysics textbooks (Nettleton, 1940; Heiland, 1946; Dobrin 1960). Figure 2 illustrates a cross-section of a gravity meter with its main mechanical parts, which are held in unstable equilibrium about a main axis, inserted in the lower section of the instrument. An increase of gravitational pull causes a slight counterclockwise rotation of a weight-arm element, connected by a vertical spring system to a pointer, which can be observed by a built-in microscope. Minute deformations due to gravity variations in the order of 1 in $10^{6}$ can be directly recorded.

In order to illustrate comparatively the net differential effect of the vertical pull of gravity arising from a subsurface void, it is assumed that any cave at a given place will have either a long horizontal cylindrical or a spherical shape. In the first case, the gravity pull exerted by the earth is considered to be distributed along the main axis, and this condition can be quantified by a simple equation which gives the value of gravity $_{(\max )}$ of a buried horizontal cylinder (Dobrin, 1960, and others) as follows:

$$
\begin{aligned}
& \mathrm{g}_{(\max )}=0.01277 \delta \frac{\mathrm{R}^{2}}{\mathrm{Z}}, \\
& \text { where } \delta=\text { density contrast, } \\
& \mathrm{R}=\text { radius of the cylinder, } \\
& \mathrm{Z}=\text { depth from surface to center of the cylinder, } \\
& \mathrm{g}_{(\max )}=\text { maximum gravity value in milligals. }
\end{aligned}
$$

For the second case, that is the buried sphere (or other equidimensional cavity), the gravity pull acts on its center and determines the following maximum readable anomaly (Dobrin, 1960):

$$
\mathrm{g}_{(\max )}=0.00852 \delta \frac{\mathrm{R}^{3}}{\mathrm{Z}^{2}} \text {; here } \mathrm{R} \text { is the radius of the sphere. }
$$

$\left.{ }^{2}\right)$ Milligal (abbreviated $\left.\mathrm{mlg}\right)=$ one thousandth of a gal. gal = acceleration of one centimeter per second per second. 
Although the given equations represent theoretical cases of differential gravity pull of a cylinder or sphere buried in a perfectly spherical earth mass, several corrections must be made (Romberg, 1958).

For instance, since the pull of gravity varies on the earth surface in inverse proportion to the square of the distance to the center of the earth (shorter at the poles than on the equator), a change of gravity with latitude must be taken into account. No latitude correction is needed, however, if the gravity observations are performed along an east-west traverse; but for every 450 feet in a south-north direction a 0.10 milligal correction must be added at mid-latitude. This figure is significant in cave detection because anomalies of one or two milligals are dealt with generally. Likewise, two corrections need to be made for altitude differences along a gravimetric traverse: (1) a correction derived from the fact that gravity becomes progressively less as altitude becomes greater; and (2) a correction required by the gravitational attraction of the rock in the layer between the datum and the elevated station. Therefore, 0.009 milligals must be added (or subtracted) for every increase (or decrease) of 0.1-foot elevation. For this reason, gravimetric stations should be accurately surveyed, closing the elevation «loops» with \pm 0.1 foot for shallow-anomaly mass determinations. It has been found that altitude errors often lower the accuracy of a field survey. In field practice, a simplified elevation control can be obtained by using a high-precision altimeter, which responds to atmospheric-pressure changes equivalent to elevation differences as small as 0.1 feet (Stripling, Broding, and Wilbem, 1949); however, a transit survey for a short traverse is more advisable.

The gravitational attraction of topographic features is not a problem on flat surfaces but is a source of error when the relief is significant. Hammer's 1939 tables might be used for any gravity traverse across a high-relief section - i.e. a traverse run from a valley floor to a mountain peak. Gravity corrections due to tidal effects become negligible when the determinations are made within a two-hour period; otherwise, tidal tables giving anomaly-time relations should be used.

\section{Cave-Detection Field Work}

In order to determine the uses and limitations of this technique, Luray Caverns of Virginia were selected as a test site. The caverns consist of a network of narrow passages connected with large rooms within a granular crystalline dolomite belonging to the lower Breekmantown Formation (Early Ordovician age). The speleo-geology has been described by several authors, the most recent being Hack and Durloo 
(1962), whose map was used for this study. After an underground tour and geologic reconnaissance, it was decided to set up gravity stations on the surface along a north-south traverse, crossing a major underground room of the caverns. The stations were spaced at 20, 40, 60, $80,100,140$ and 180 feet respectively from a central station coinciding with the projection of the room on the surface. A transit traverse was carried out, thereby providing control for elevation differences needed for a later correction of gravity values at each place. The instrument was constantly checked for drift by re-reading values at a nearby base station located on concrete.

The Luray work, as well as a second group of field determinations, provided sufficient field data for setting up some practical conclusions which are presented below and which are related to the theoretical equations already presented. The determining factor is based on the fact that there is a shape/size/depth relationship governing whether or not a cave can be detected with the existing equipment and normal precision of field work.

These values for a horizontal tunnel buried at variable depths are given in table 1, where the depth of the buried tunnel from surface to center is called $\mathrm{Z}$; $\mathrm{R}$ symbolizes the tunnel radius; and $\pi \mathrm{R}^{2}$, its cross-sectional area. The figures detailed in table 1 have been found through field testing, although theoretically it is possible to obtain them by calculation as follows:

If the instrument allows readings of 0.1 milligal,

$$
0.1 \mathrm{mlg}=0.01277 \delta \frac{\mathrm{R}^{2}}{\mathrm{Z}}
$$

is obtained.

Using 2.7 as the average density for limestone, and inserting the value,

$$
0.1 \mathrm{mlg}=0.03448 \frac{\mathrm{R}^{2}}{\mathrm{Z}}
$$

is obtained; consequently,

$$
\frac{\mathrm{R}^{2}}{\mathrm{Z}}=2.89
$$

Given values for $R$, the corresponding $Z$ values can be found; and the cross-sectional area found by computation. Likewise, by using the example of a spherical cavity in limestone, the following derives: 


$$
\begin{gathered}
\mathrm{g}_{(\max )}=0.00852 \delta \frac{\mathrm{R}^{3}}{\mathrm{Z}^{2}} \\
\text { then, } 0.1 \mathrm{mlg}=0.023 \frac{\mathrm{R}^{3}}{\mathrm{Z}^{2}} \\
\text { and, } \frac{\mathrm{R}^{3}}{\mathrm{Z}^{2}}=4.3 \text { Feet }
\end{gathered}
$$

In the same manner, knowing the value of $\mathrm{R}$, the value of $\mathrm{Z}$ can be derived for any spherical buried cavity which would produce an anomaly of $0.1 \mathrm{mlg}$, since $\mathrm{R}^{3} / \mathrm{Z}^{2}$ must equal 4.3 Feet.

Tables I and II are self-explanatory and indicate furthermore that any possible rule of thumb for shallow cave detection must follow the non-linear relationship between radius of the cavity, R., and the depth from surface to its center, $Z$. This should always be taken into account during any field program aimed at void detection in areas where small caverns are suspected. For this reason, whenever possible, the explorer should make an inventory of shape/size/depth relation among known caverns of the area under prospection in order to envisage what chances he would have for locating new caverns by this technique.

More specifically, by using standard gravity meters and providing a good control in field measurements and correction adjustments, it can be stated that: (1) For a limestone tunnel $\mathrm{R}^{2} / \mathrm{Z}$ must be equal or larger than 2.89 feet in order that the gravity meter directly above the cavity center show at least an $0.1 \mathrm{mlg}$. or larger anomaly; and (2) For an equidimensional cavity in limestone $\mathrm{R}^{3} / \mathrm{Z}^{2}$ must be equal or larger than 4.3 feet.

Figure 3 summarizes the data obtained from detection attempts carried out at Luray Caverns-Main Hall and the calculated value of a larger void. Curve $\mathrm{A}$ is the deflection caused by the gravity pull of the Main Hall, and curve B, the one calculated for a larger theoretical void. It was found that the 46-foot buried, odd-shaped Main-Hall, which has an approximate radius of 19.7 feet, gives a maximum gravity of $.05 \mathrm{mlg}$., if a single direct reading is performed above it.

Since $0.05 \mathrm{mlg}$ cannot be directly read by a single observation, the cavity will not be detectable, unless several trials are made in order to refine the reading statistically. ${ }^{3}$ )

$\left.{ }^{3}\right)$ The smallest single reading value of the Worden gravity meter used is $0.088 \mathrm{mlgs} /$ dial divisions, which in the lowest practical terms corresponds to 0.1 milligal. Better resolution in the order of 0.0114 milligals - with \pm $0.025 \mathrm{mlgs}$. of probable error - has been obtained statistically after a series of readings were performed on the same stations (average mean, standard deviation, and standard error also found), and a final adjusted reading was calculated and plotted by curve-fitting techniques. 
The same Main Hall would give anomalies of $0.028,0.010$ and 0.003 milligals at distances of 40,80 , and 140 feet away from Station 0 (Figure 3 ). The decrease of these gravity values has been calculated by using a nomogram of Nettleton's textbook (1942).

If the Main Hall at Luray Caverns had measured 49 feet in width, the gravity station above it would have given a 0.1 milligal reading difference in comparison with stations at the end of the gravity traverse. Conditions such as this - illustrated by curve b on figure 3 are present at Woodland Caverns (Liberty Bell Room), also visited by this writer, and at other localities (not only in limestone but also in volcanic rocks - Williams, 1963). It should be stressed here that the size of caverns in limestone does not depend on the rock thickness above the cavern ceiling. They could have almost any size as long as the prevailing geologic stress of the surrounding area remains constant (Scheidegger, 1961).

It is evident that a naturally occurring cave would not be detected by the gravity method unless its shape/size/depth relations fit into the minimum values already given. It would be a cumbersome and impractical task to attempt to locate caverns by a gravity-determination program in an area where limestone outcrops are present without knowing in advance their possible existence as inferred from a geologic analysis. Caves are not found everywhere within limestone, and a pre-selection of cave areas is required in order to obtain not only indicative data about possible caves (by means of sink holes, drainage patterns, etc.) but also to determine conveniently what prospecting techniques should be used. Such a survey should utilize the geologic literature, and in addition, geophysical information already available in the form of Bouger anomaly maps. These maps (mostly made by petroleum exploration teams) depict gravity anomalies (some with contours of 1 milligal) produced, for example, in Iraq by caverns within anhydrite stocks (Colley, 1962).

It seems that although the gravity-meter technique has several limitations, it offers important possibilities for cave locating under the proper conditions.

\section{ACKNOWLEDGEMENT}

Part of the field work was accomplished with the valuable help of Morris McCord, Texas Instruments Incorporated, Dallas, Texas.

\section{ABSTRACT}

For gravimetric investigations, a naturally occurring limestone cave may be compared with a buried empty sphere or cylinder, depending on its shape. The practical limit of detection for a subsurface void, utilizing available 
equipment (Worden gravity meter) and standard field procedure, is 0.1 milligal. Most corrections normally required by the gravimetric method may be neglected in cave detection, but the altitude control for the field traverse must have an accuracy of \pm 0.1 foot.

The detectability of a limestone cave, based on field work done at Luray Caverns, Virginia, and at other localities, is related to its shape, Radius (R), and distance from surface to the cave center (Z). It follows a non-linear relationship. Detectability is possible only when

$$
\frac{\mathrm{R}^{3}}{\mathrm{Z}^{2}}=4.3 \text { feet, and } \frac{\mathrm{R}^{3}}{\mathrm{Z}}=2.89 \text { feet }
$$

for a cave room and a cave passage respectively.

\section{ZUSAMMENFASSUNG}

Für gravimetrische Untersuchungen kann eine natürlich erscheinende Kalksteinhöhle mit einer vergrabenen Kugel oder einem Zylinder - von der Gestalt abhängig - verglichen werden. Die praktische Grenze der Feststellung einer Suboberflächenleere, bei Benützung von einer zur Verfügung stehenden Ausrüstung (Worden Schwerkraftmesser) und vom üblichen Vorgehen auf dem Felde bei ähnlichen Forschungen ist 0,1 Milligal. Die meisten bei der gravimetrischen Methode erscheinenden Korrekturen können in der Höhlenforschung vernachlässigt werden, jedoch muß die Höhenkontrolle für den Querschnitt des Feldes eine Genauigkeit von $\pm 0,1 \mathrm{Fuß}$ aufweisen.

Die Entdeckbarkeit einer Kalksteinhöhle, auf in den Luray Höhle in Virginia und in anderen Localen durchgeführte Felduntersuchung basiert, hängt von der Form ab, Radius (R) und Entfernung der Oberfläche zum Mittelpunkt der Höhle (Z). Sie befolgt ein nicht lineares Verhältnis. Entdeckbarkeit ist nur möglich wenn

$$
\frac{\mathrm{R}^{3}}{\mathrm{Z}^{2}}=4.3 \mathrm{FuB} \text { und } \frac{\mathrm{R}^{2}}{\mathrm{Z}}=2.89 \mathrm{Fu} \beta
$$

für einen Höhlenraum und einen Höhlengang.

\section{REFERENCES}

Billings, M. P. - 1952: Structural geology : 2nd ed. : 1-514. Prentice-Hall Inc., New York.

Colley, G. C. - 1962: The detection of caves by gravity measurements: Geophys. Prospecting 11: 1-9.

Doв Rin, M. - 1960: Introduction to geophysical prospecting : 2nd ed.: 1-446. McGraw-Hill Inc., New York.

Goetz, J. - 1957: A gravity investigation of a sulfide deposit. Geophysics 23: 606-623.

Наск, J., and Derloo, L. - 1962: Geology of Luray Caverns, Virginia: Virginia Div. Mineral Resources, Rept. Invest. (3): 1-43.

Ham MeR, S. - 1939: Terrain corrections for gravimeter stations. Geophysics 4: 184-194. 
-, Nettleton, L. and Hastings, W. - 1945: Gravimeter prospecting for chromite in Cuba. Geophysics 10: 34-39.

Heiland, C. - 1946: Geophysical exploration. 1-1013 Prentice-Hall Inc., New York.

Nettheton, L. - 1940: Geophysical exploration. 1-444 Prentice-Hall Inc., New York.

Nicol, A. L. - 1951: Application of geophysical methods to location of cavities in residual soil and caverns in coralline limestone 1-24. U.S. Geol. Survey, Military Geology Branch.

Stripling, A., Broding, A. and Wilbem, E. - 1949: Elevation survey by precision barometric means. Geophysics 14: 543-557.

Romвев, F. - 1958: Key variables of gravity. Geophysics 23: 684-700.

- 1961: Detecting voids with gravimetry. 1-40 and appendix. U.S. Air Force, Cambridge Research Lab., Contract AF19 (604) 8348.

Scheid Eg Ger, A. - 1961 : Theoretical geomorphology. 1-333 Springer-Verlag, Berlin.

Williams, L. A. - 1963: Lava tunnels on Suswa Mountain, Kenya. Nature. 199: 348-350.

\section{EXPLANATION OF PLATES 18 (1)-21 (4)}

Portable, self-powdered Worden gravity meter (manufactured by Texas Instruments) used for gravity detection of caverns.

\section{PLATE $19(2)$}

Diagramatic cross-section of the gravity meter illustrated in figure 1. See text for details.

$$
\text { PLATE } 20 \text { (3) }
$$

Curve A: Gravity anomaly for the Luray Caverns-Main Hall with 19.7foot radius ( $\mathrm{Z}=65$ feet).

Curve B: Gravity anomaly for a theoretical void with 24.5 -foot radius $(\mathrm{Z}=65$ feet $)$.

PLATE 21 (4)

Nomenclature used for calculating gravimetric anomalies of tunnel- and room-shaped voids. 


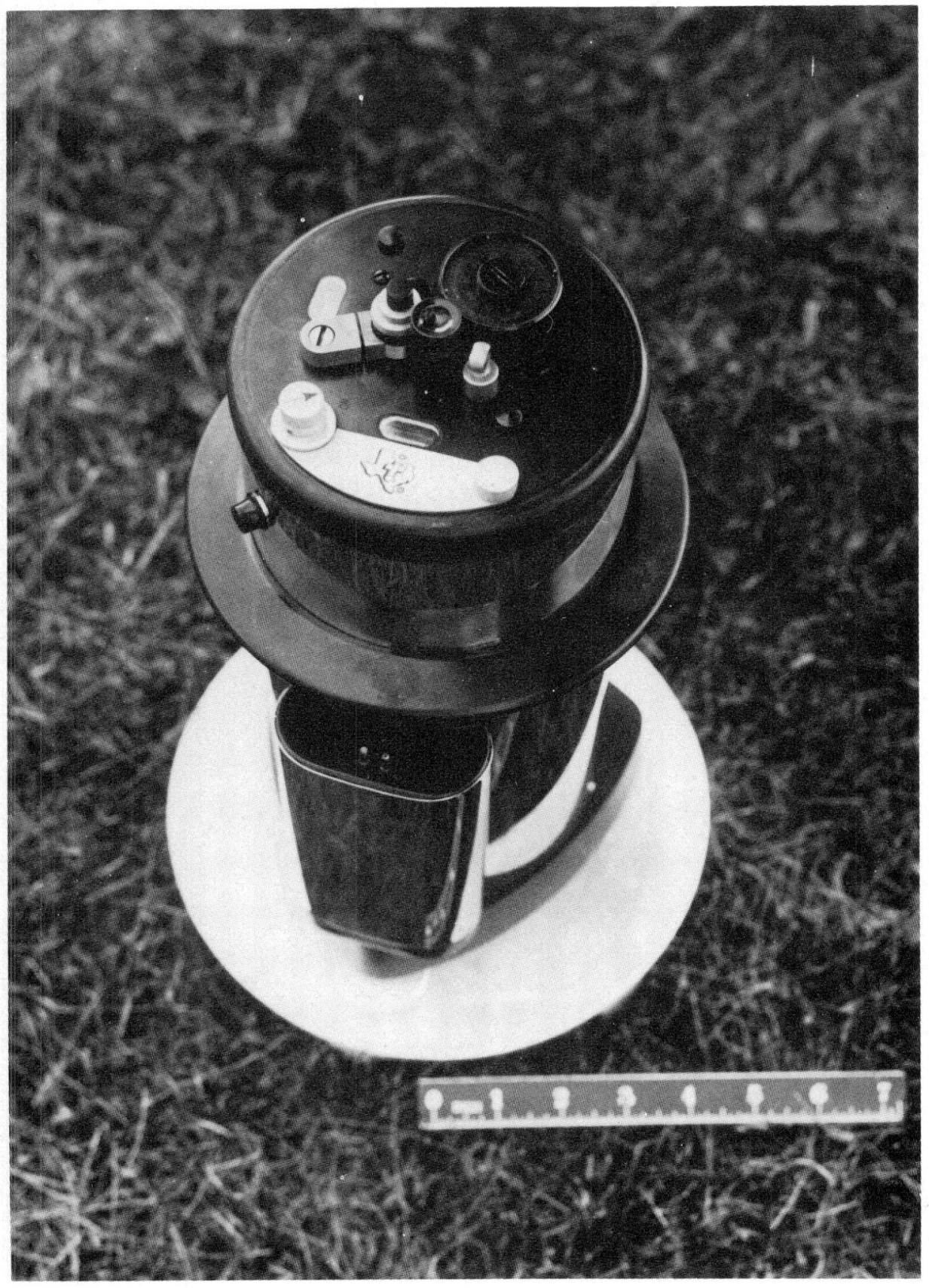




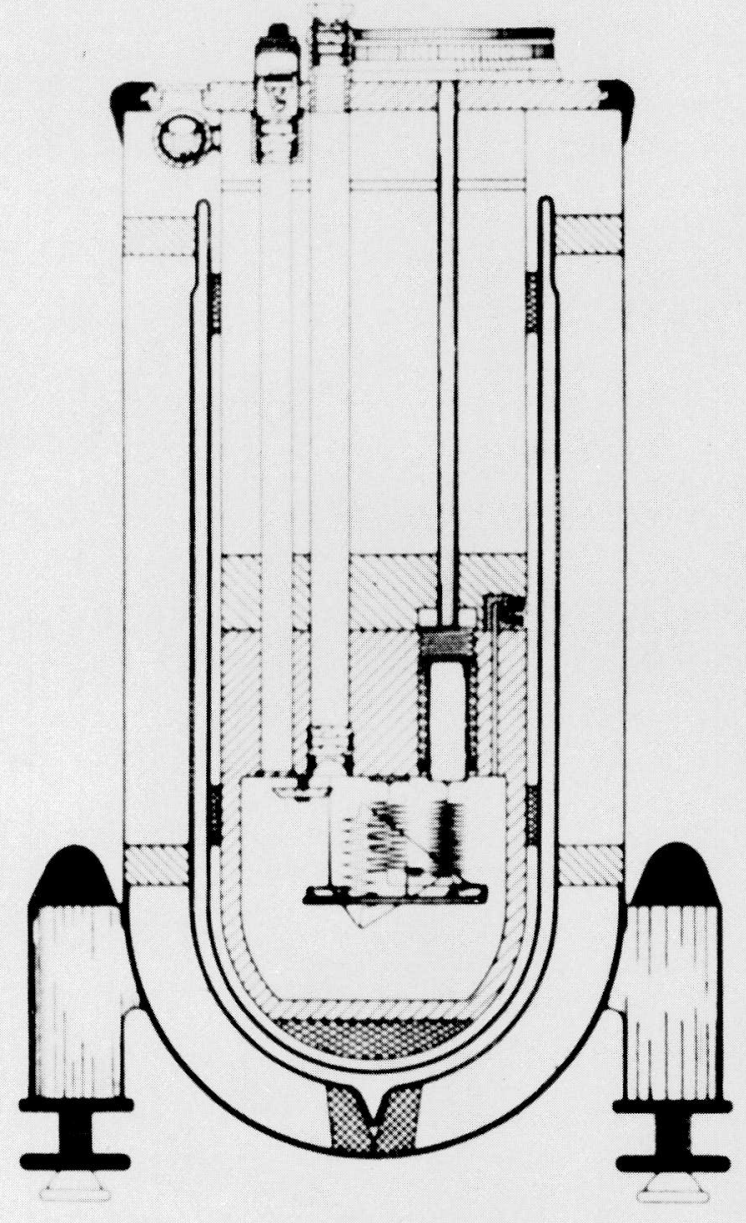




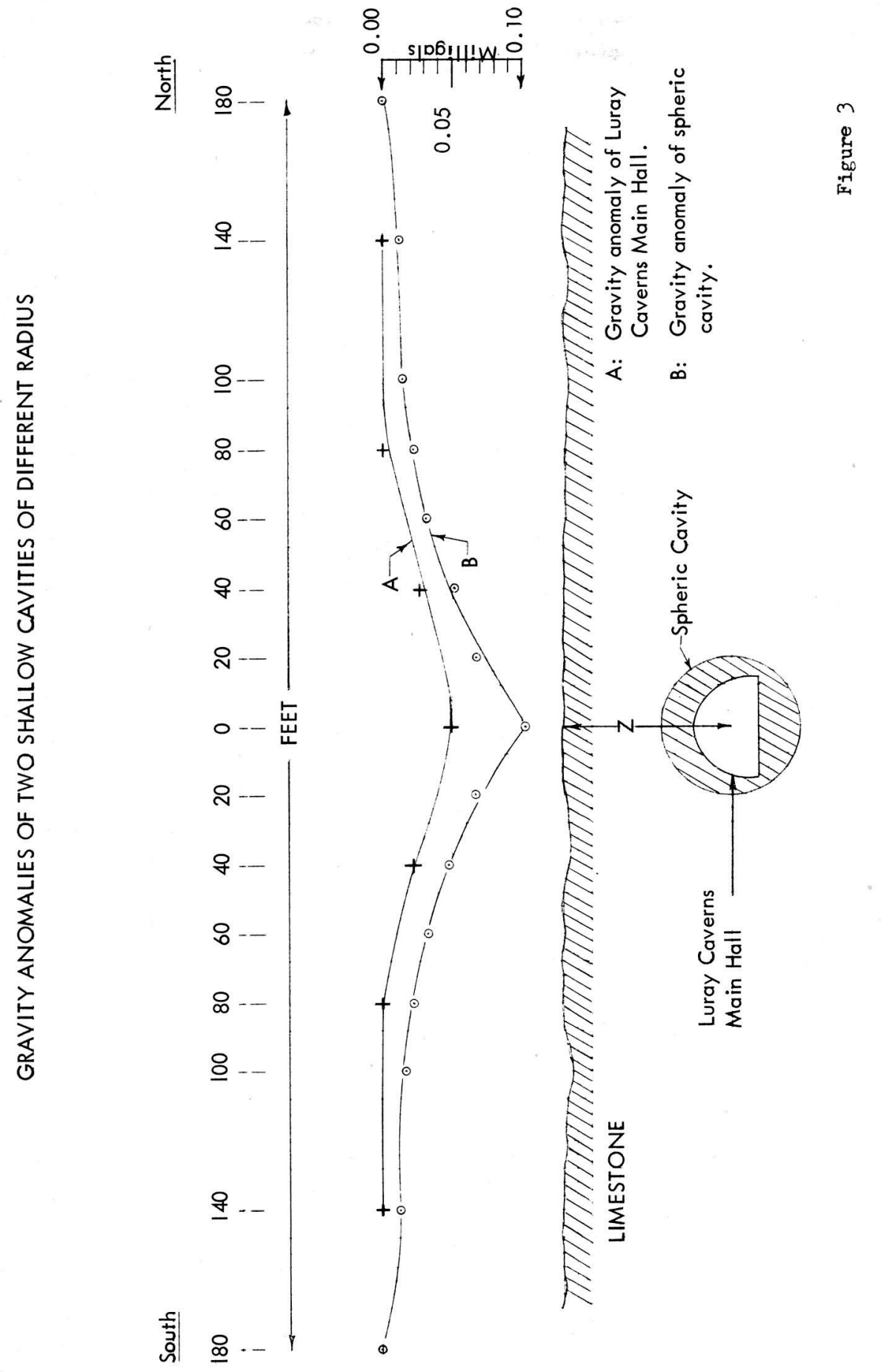


TABLE I

TUNNEL SHAPE

(see text for explanation)

\begin{tabular}{|c|c|c|c|}
\hline$Z$ & $R^{2}$ & $R$ & $J^{2} R^{2}$ \\
\hline & & & \\
10 & 28.1 & 5.3 & 88.2 \\
15 & 42.1 & 6.5 & 132.2 \\
\hline
\end{tabular}

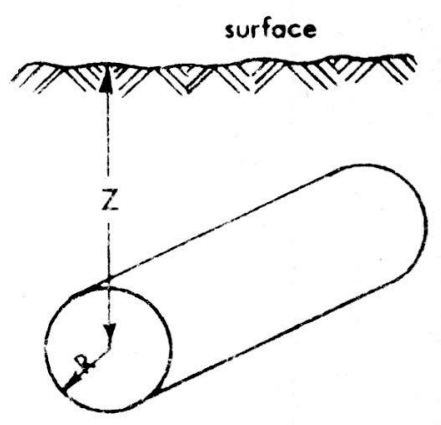

TABLE \|

ROOM SHAPE

(see text for explanation)

\begin{tabular}{|c|c|c|c|c|}
\hline$Z$ & $Z^{2}$ & $R^{3}$ & $R^{2}$ & $\begin{array}{c}\text { Sphere Volume } \\
4 / 3 J \mathrm{~J} R^{3}\end{array}$ \\
\hline 10 & 100 & 430 & 7.6 & $1801 \mathrm{ft}^{3}$ \\
15 & 225 & 1167.5 & 10.5 & $4391 \mathrm{ft}^{3}$ \\
\hline
\end{tabular}

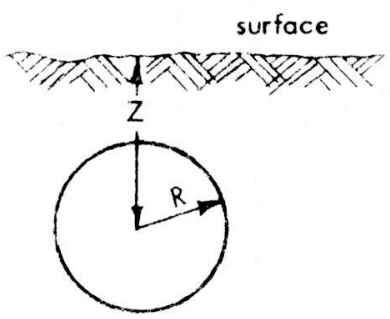

